\title{
Inflation Threshold Effects on Growth in Ethiopia: Evidence from Food and Non-food Sectors
}

\author{
(Date Written: January 01, 2020)
}

\author{
Dagmawe Tenaw $^{1 *}$ and Helen Demeke ${ }^{2 *}$ \\ *Department of Economics, Dire Dawa University, \\ Dire Dawa, Ethiopia \\ 1Email: dagymanta@gmail.com \\ 2Email: helud19@gmail.com
}

\begin{abstract}
Economists have long been interested in examining inflation-growth nexus. Nevertheless, the nature of their relationship and the optimal level of inflation threshold for economic growth have still remained controversial in both theoretical and empirical works. Accordingly, this study investigates the existence of threshold effects of inflation on economic growth in Ethiopia over the period 1975-2018 using a Two-regime Threshold Auto-regressive (TAR) model. The study mainly departs from previous works since it estimates sector-specific inflation threshold level in food and non-food sectors. Our preliminary analyses clearly reveal that inflation in food sector has become more volatile, lesspersistent and key contributor to the general inflation as compared to its non-food counterpart. Further, The TAR model results and robustness checks indicate the existence of inflation threshold in a range of 910\%. In particular, the threshold level for food inflation is $10 \%$ and $8 \%$ for non-food inflation. In all cases, our results robustly confirm growth-detrimental effects of inflation after the threshold levels. After all, this study suggests the need for considering specific behaviors of food and non-food prices, and implementing appropriate fiscal and monetary policies to bring inflation down to a single-digit level.
\end{abstract}

Key Words: Food and non-food inflation; Threshold; TAR model; Economic Growth; Ethiopia 


\section{Introduction}

The Ethiopian economy has experienced different paths of inflation and growth over the last four decades. Compared to other developing countries, Ethiopia has had a relatively stable and low inflation in its history particularly prior to 2003/04. For instance, according to World Bank (2017), the average annual inflation rate during the Derg period (1974-1991) was about 8.3\% and it was only 5.2\% during the period between 1980/1-2003/4. Since 2004/05, however, the economy has deviated from its historical trends of stable price and the rate of inflation increased from $3.3 \%$ in $2004 / 05$ to $44.4 \%$ in $2008 / 09$ and $33.2 \%$ in $2011 / 12$. In some cases, the major inflationary periods were associated with recurrent droughts and world financial crisis of 2007/08. Similarly, the Ethiopian economy was characterized by its low growth rate and highly dominated by the agricultural sector over a long period. However, in the last few decades, a continuous and rapid growth rate has been achieved. According to World Bank (2017), the country has ever attained a double-digit economic growth started since 2004/05, which was $10.9 \%$ annually on average.

Economists have a long history of interest in the investigation of the relationship between inflation and economic growth. Nevertheless, the nature of relationship between the two macroeconomic variables and appropriate level of inflation target (the threshold level of inflation beyond which inflation is harmful to growth) have remained controversial and debatable issues in both theoretical literatures and empirical findings. Quite simply, there has been no clear-cut conclusion about the nature of inflation-growth relationship. In this respect, as cited in various literatures, Friedman (1973) summarized the inconclusive nature of the relationship between inflation and economic growth that historically, all possible combinations have occurred: inflation with and without growth (development), no inflation with and without development.

It has been widely believed that moderate and stable inflation rates promote economic growth of a country. In contrast, high and variable inflation rate has distortional effects and serious implications on economic growth. In this regard, as noted in Ashagrie (2015), recently evolving empirical works suggest that inflation targeting in developing countries can lead to significant improvements in terms of inflation and output volatility. However; the right (optimal) level of inflation target for developing countries still remains a controversial issue. For instance, Khan 
and Senhadji (2001) suggested that the inflation threshold for developing countries is between 7$11 \%$. While, Kremer et. al. (2011) found an inflation target of about $17 \%$ for non-industrialized economies. Further Ndoricimpa (2017) confirmed a threshold level of $9 \%$ for low-income and $6.5 \%$ for middle income African countries.

Like the empirical evidences at global level, the empirical studies undertaken in Ethiopian context have shown mixed and conflicting findings on inflation-growth relationship. For instance, a study conducted by Fekadu (2012) found that inflation does not have any significant effect on economic growth. On the other hand, some other studies like Admasu (2014), Rao and Abate (2015), and Abis and Cherkos (2018) revealed a non-linear inflation-growth relationship. Concerning the threshold level, these studies suggested threshold level of 9-10\%. In contrast, the findings in Ashagrie (2015) did not support the existence of inflation threshold effect.

Hence, in such complex and controversial situations where the existing empirical literatures are far from reaching conclusive agreements, it is worth and interesting to further investigate the nature of inflation-growth nexus and the existence of inflation threshold level in Ethiopia in recent days. In addition, to the best of our knowledge, the previous empirical literatures conducted on inflation-growth relationship considered the overall inflation and did not separately take the food and non-food inflation in to account (did not undertake sector-specific inflation analysis). Nevertheless, the two major components of inflation might give a different picture with each other and as compared to the overall inflation as they exhibit different degree of volatility and persistence, trends, price setting process and associated with different factors (sources of fluctuation). Further, the channels through which food and non-food inflation can affect the economy and their impact ${ }^{1}$ on the economy are also quite dissimilar. As a consequence, a single economy-wide inflation targeting would not be appropriate for optimal growth as it may favor only some sectors of the economy. This study, therefore, examines the existence of nonlinearities (threshold effects) in inflation-growth nexus in Ethiopian context over 1975-2018 considering inflation in food and non-food sectors separately using disaggregated data. If non-linearity does exist, what level of inflation is likely good for growth? We also assess and compare the degree of volatility and persistence of inflation in food and non-food items.

\footnotetext{
${ }^{1}$ For instance, non-food inflation tends to have more adverse impact on income inequality in both rural and urban areas as compared to food counterparts (see Walsh and Yu, 2012).
} 
The rest of the paper is structured as follows. Section two reviews different theoretical and empirical literatures about the growth-inflation relationship. The third section presents the data and methodology of this study. Section four is concerned about findings and discussions of the study on inflation-growth nexus in Ethiopia. Finally, the conclusions and recommendations of the study are presented in the fifth section.

\section{Brief Review of Literatures}

\subsection{Theoretical review}

Different theoretical literatures have been evolved on the nature of inflation-growth nexus and have come up with mixed conclusions and hence no general consensus among these theories. For instance, Gokal and Hanif (2004) noted that although the relationship between inflation and economic growth was not explicitly explained by classical economists, it is implicitly suggested that the two economic variables have a negative relationship as indicated by the reduction in firms profit level through higher wage costs. The Keynesian school, on the other hand, illustrated inflation-growth relationship with the help of Aggregate Demand and Aggregate supply curves and suggested a stable long-term positive relationship between inflation and growth. In contrast, due to rigidity of wages and prices and the time it takes to restore to long run equilibrium, the Keynesians posited that there is no visible short run relationship between the two variables. Based on the Quantity theory of Money (QTM) and neutrality of money, Monetarist theory of Milton Friedman $(1968,1976)$ argued that inflation and growth have a positive short run and no long run relationship as long run prices may have no real effect on growth (Gokal and Hanif, 2004).

Further, the theoretical review on neo-classical school indicated that different models of the school could yield different results with regard to the relationship between inflation and growth. The Tobin (1965) model argued that money is a substitute for capital and causes inflation to have a positive effect growth in long run. In Sidrauski (1967) model, money is regarded as superneutral and hence no linkage between inflation and growth. In addition, Stockman (1981) model considers money as complementary to capital and posited a negative inflation-growth relationship (see Gokal and Hanif, 2004; Adusei, 2012, Chu et al,. 2019). On the other hand, Abis and Cherkos (2018) noted that the new-Keynesian view suggested that inflation whether 
anticipated or unanticipated has an overall negative impact on economic growth. Recently, many economists believed that there is no linear relationship between inflation and economic growth. In this regard, Adusei (2012) mentioned Huybens and Bruce (1998)'s new class of models in which inflation has a negative effect on long-run growth only above the threshold level of inflation.

Generally speaking, different theoretical literatures indicated that there is no clear-cut and straightforward inflation-growth relationship; rather the linkages depend on the assumptions about the economy identified and on the set up of the models. Accordingly, inflation may have positive, negative, neutral, or non-linear relationship on economic growth.

\subsection{Empirical Reviews}

Until the mid of 1970s, there was little empirical evidence on the relationship between inflation and economic growth. Like the theoretical models, results of empirical studies change through time from the widely known traditional point of view of no relationship between inflation and economic growth to non-linear relationship in recent years. Many economists argued that low but positive inflation is good for the improvement of a given economy. In this section, a few general observations on different empirical literatures recently conducted on the relationship between inflation and economic growths across different parts of the world are highlighted in table A1 (see appendix 1). As can be shown in Table A1, the findings of single-country and cross-country studies conducted in different countries of the world reveal inconclusive evidences concerning the relationship between inflation and growth. We also review that the threshold level of inflation for economic growth is country specific: it depends on specific macroeconomic environment.

Likewise, empirical studies undertaken in Ethiopian context on inflation-growth nexus have shown mixed results. For instance, a study conducted by Fekadu (2012) over a period 1980-2011 using Vector error correction model found that inflation does not have any significant effect on economic growth. On the other hand, some other studies like Admasu (2014), and Abis and Cherkos (2018) following the Khan and Senhadji (2001) methodology; Rao and Abate (2015), among others revealed a non-linear relationship between inflation and economic growth in Ethiopia. Concerning the threshold level, these studies recommended a 9-10\% threshold level of 
inflation, beyond which inflation has a negative influence on economic growth. In contrast, Ashagrie (2015) investigated a study using Hansen's Threshold Autoregressive model over the period 1971-2013 and the results did not support the existence of threshold effect between the two variables (non-existence of non-linearity in inflation-growth nexus). Hence, it is quite interesting to further investigate the existence of nonlinearities in inflation-growth nexus (whether threshold effects of inflation on growth do exist) in Ethiopian context over recent days. How low should inflation be?

\section{Data and Methodology}

\subsection{Type and Source of Data}

Annual time series secondary data was primarily used to conduct this study, which was collected from annual and periodical reports of National Bank of Ethiopia (NBE), Ministry of Finance and Economic Development (MOFED), Central Statistical Authority (CSA), United Nations Conference on Trade and Development (UNCTAD) and World Bank (WB). Table 3.1 presents the description and summary statistics of variables over 1975-2018.

\section{Table 3.1: Description of variables and Summary Statistics (1975-2018)}

\begin{tabular}{cccccc} 
Variable & Description & Mean & Std. Dev. & Min & Max \\
\hline RGDP & GDP at constant 2011 national prices & 333000 & 398000 & 102000 & 1720000 \\
RGDP-PC $^{2}$ & Real GDP per capita (USD) & 241.45 & 96.09 & 143.02 & 532.72 \\
food $^{2}$ & Inflation in food sector & 11.227 & 18.362 & -18.292 & 78.268 \\
Non-food & Inflation in non-food sector & 7.935 & 7.477 & -5.383 & 27.842 \\
inflation & General (headline) inflation & 9.846 & 13.091 & -11.823 & 55.241 \\
Labor force & Total labor force & $2.76 \mathrm{e}+07$ & $1.14 \mathrm{e}+07$ & $1.40 \mathrm{e}+07$ & $5.19 \mathrm{e}+07$ \\
investment & Gross capital formation(\%GDP) & 24.172 & 7.411 & 12.871 & 39.417 \\
expenditure & Government expenditure (\%GDP) & 11.702 & 2.554 & 8.138 & 19.132 \\
M2/GDP & Broad money (\%GDP) & 28.164 & 7.132 & 14.208 & 41.178 \\
openness & Trade (export +import) (\% GDP) & 30.618 & 11.292 & 12.242 & 51.057 \\
\hline
\end{tabular}

Note: the total number of observations for all variables is 44 .

\subsection{Model Specification}

${ }^{2}$ Food price index comprise bread and Cereals; Meat; Fish and Seafood; Milk, Cheese and Eggs; Oil and Fats; Fruits; Vegetables and Pulses, Sugar, Honey and Chocolate; Food Products and Non-alcoholic beverages, while food-price index includes Alcoholic Beverages; Cigarettes and Tobacco; Clothing and Footwear; House Rent, Construction Materials, Water, and Fuel and Power; Furniture, Furnishing, Household Equipment and Operation; Health; Transport; Communication; Recreation, Culture; Education; Restaurants and Hotels; and Miscellaneous Goods and Services. 
In order to reach our objective of investigating the threshold effect in inflation-growth relationship, we start with the following basic regression model.

$$
Y_{t}=\alpha_{0}+\alpha_{1} P_{t}+\beta X_{t}+u_{t}
$$

In which $Y_{t}$ and $P_{t}$ represent real GDP and inflation at a time $(\mathrm{t}) . X_{t}$ is a vector of other growth determinants and $\beta$ is a matrix of their coefficients. Concerning to other explanatory variables to be included in the empirical analysis, there are a large set of growth regressors that can be potentially included in the regression. Further, the growth theories do not provide exact list of growth determinants. As a result, as can be seen in table 3.1, we incorporate different supplydriven and demand-side growth regressors in our model, mainly based on different growth theories, (particularly the neo-classical and endogenous growth theories) and following different empirical literatures (Yilmazkuday, 2011; Ashagrie, 2015; Rao and Abate, 2015; Ayyoub, 2016; Ndoricimpa, 2017, among others).

\subsubsection{Modelling Inflationary Threshold Effects on Growth}

Here, we estimate the appropriate threshold level of inflation for growth since the detrimental effect of inflation on growth may not be universal. Accordingly, a number of recently conducted empirical works on inflation-growth nexus focus on the non-linear relationship. Majority of empirical studies estimated the existence of non-linear relationship between inflation and growth using a threshold model developed by Khan and Senhadji (2001) and quadratic specification (including the linear and quadratic terms of inflation as regressors in the model). The threshold model of Khan and Senhadji (2001), however, requires a large data set to make valid statistical inferences (Rutayisire. 2015) while the quadratic specification would erroneously yield a threshold value (turning point) as linear and quadratic terms are highly correlated. Further, Haans and $\mathrm{He}$ (2016) remarked that a significant coefficient of quadratic term alone may not be sufficient to establish a quadratic relationship.

In this paper, we employed a Threshold Auto-regressive (TAR) model, which was first proposed by Tong(1978) and further developed by Tsay (1989), Hansen (1996, 2000), to estimate the threshold effects of inflation on economic growth. TAR model is a popular regression technique to estimate economic relationship which is subject to structural changes or switching regimes. It is a relatively simple model to specify, estimate, and interpret. The main idea behind this model 
is, as noted in Aydin and Esen (2017), determining one or more threshold values thereby allowing the estimation of different linear models for different regimes and to observe the size of any differences in effect if non-linearity exists. In our case, we consider the two-regime TAR model to estimate the non-linear relationship between inflation and growth as follows:

$$
\begin{aligned}
& Y_{t}=\alpha_{1} P_{t}+\beta X_{t}+u_{t} \text { if } P_{t}<T \\
& Y_{t}=\alpha_{1} P_{t}+\beta X_{t}+u_{t} \text { if } P_{t} \geq T
\end{aligned}
$$

Where $X_{t}$ represent variables whose parameters do not vary across regimes, $P_{t}$ is regimesplitting threshold variable (a variable that may cause regime change), $\mathrm{T}$ is the threshold value (a value indicating regime switching). Since the threshold value is not known a priori, it has to be estimated along with other parameters. Using a dummy variable $D(T)=\left\{\begin{array}{l}D=0 \text { if } P_{t}<T \\ D=1 \text { if } P_{t} \geq T\end{array}\right.$ and setting $P_{t}(T)=P_{t} * D(T)$, we may combine equations (3.1a) and (3.1b) into a single equation as:

$$
Y_{t}=\alpha_{1} P_{t}(T)+\beta X_{t}+u_{t}
$$

Given the threshold variable and the linear specification, we estimate the threshold value and the parameters of the TAR model using non-linear least squares as a natural approach for estimation and the optimal threshold value is the value at which Residual sum of squares (RSS) is minimized. Finally, we expect that inflation has a positive or insignificant effect on growth below the threshold level (at lower inflation regime) and the adverse effect will appear once inflation surpasses the threshold level (at high inflation regime).

\section{Results and Discussion}

\subsection{Trends in inflation}

As depicted in figure 4.1, Inflation in Ethiopia has shown a fluctuating trend (ups and downs) over the last four decades. The major inflationary episodes are associated with agricultural supply shocks due to recurrent drought, conflicts, World financial crisis (2007/8), and housing and construction boom in urban areas during the study period. While, the deflationary trends particularly in food items might be attributed to good harvests and significant food aid inflows (2001/02). The figure further shows that average annual inflation in non-food sector has been 
moderate as compared to that of food counterpart in Ethiopia during the study period. We observe that fluctuating trend in general inflation was caused by substantial ups and downs of food inflation. We can, therefore, conclude that inflation in food sector has been a great contributor to general (headline) inflation ${ }^{3}$ in in Ethiopia during the study period.

\section{Figure 4.1: Food, non-food and general inflation trends in Ethiopia (1975-2018)}

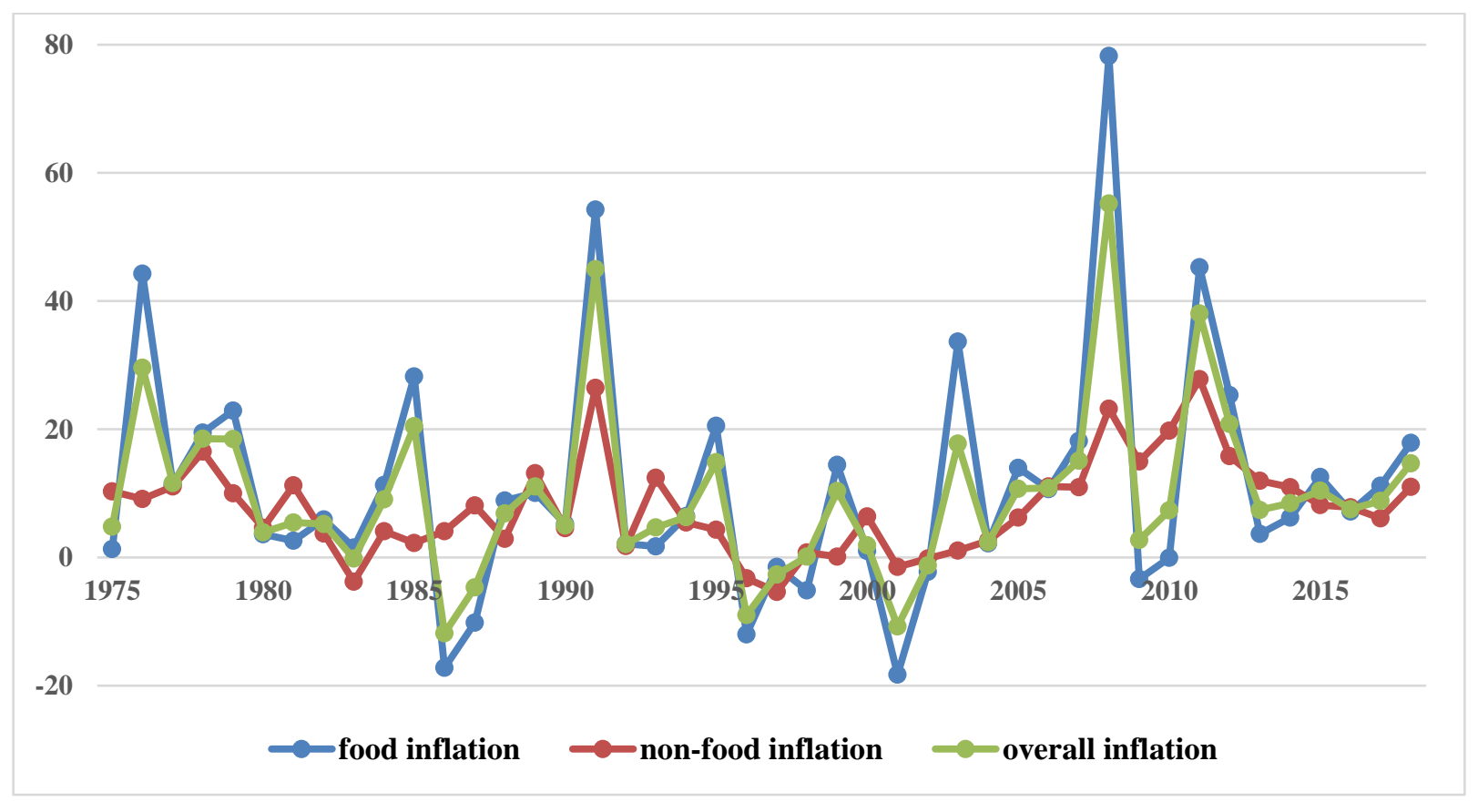

\subsection{Volatility and Persistence of Inflation in Ethiopia}

Volatility, in our context, refers to the degree of price variations (ups and downs) over the specified time. Smaller price changes (movements) are indicative of low volatility, while high volatility signifies large price changes. Volatility, as noted in different literatures (Alper et al., 2016, among others), is measured by standard deviation and coefficient of variation ${ }^{4}$. As observed in table 4.1, both measures indicate that food inflation is more volatile as compared to non-food inflation in both 1975-1991 and 1992-2018 periods.

\footnotetext{
3 Further, high and strongly significant Pearson's and Spearman's correlation coefficients indicate a strong correlation between food and general inflation (they are statistically very similar). High inflationary periods are associated with high inflation in food items. (Pearson=0.98, and Spearman= 0.96).
}

${ }^{4}$ Coefficient of variation, $C V=\frac{\text { Standard Deviation }}{\text { mean }} * 100$. 
Table 4.1: Volatility of Inflation

\begin{tabular}{ccccccc}
\hline \multirow{2}{*}{ Time period } & \multicolumn{2}{c}{ Food inflation } & \multicolumn{2}{c}{ Non-food inflation } & \multicolumn{2}{c}{ overall inflation } \\
\cline { 2 - 7 } & Std. dev. & CV $(\%)$ & Std. dev. & CV $(\%)$ & Std. dev. & CV $(\%)$ \\
\hline $1975-1991$ & 17.84 & 148.79 & 6.79 & 83.39 & 13.23 & 126.13 \\
\hline $1992-2018$ & 19.00 & 176.84 & 8.00 & 102.53 & 13.24 & 140.24 \\
\hline $1975-2018$ & 18.36 & 163.56 & 7.48 & 94.22 & 13.09 & 132.97 \\
\hline
\end{tabular}

The higher volatility of inflation in food sector might be associated with variation in agricultural production in between harvests due to change in weather conditions, inelastic demand for agricultural products, higher share of income spent for food and rise of energy prices. In general, higher volatility observed in food inflation drives the general (overall) inflation to be more volatile in Ethiopia during the study period (1975-2018).

On the other hand, Dias and Marques (2005) defined persistence of inflation as the tendency of inflation to converge slowly to its equilibrium (long run level) after a shock. There are various alternative measures of persistence of inflation. As noted in Dias and Marques (2005) and Alper et al., (2016), the most common measure is the sum of the autoregressive coefficients (SARC ${ }^{\mathbf{5}}$ ) in univariate inflation equation, in which a higher estimate of the SARC indicates greater persistence. An alternative non-parametric measure of persistence proposed by Marques (2004) is absence of mean reversion ${ }^{6}(\gamma)$. It is defined as the unconditional probability of a process not crossing its mean in period, $\mathrm{t}$ (or simply one minus the degree of mean reversion). It measures how frequently a given time series reverts to its mean. A non-persistent series must cross its mean very frequently. In short, Values of $\gamma$ significantly above 0.5 indicate significant persistence (Dias and Marques, 2005). In our case, we use both measures of persistence to ensure the robustness of our results. Note that we use the SARC obtained from the estimation of Dickey-Fuller GLS unit-root test of Elliott et al (1996): a modifying the Dickey-Fuller test using

\footnotetext{
${ }^{5}$ Assuming that inflation ( $\pi$ ) follows univariate $\mathrm{AR}(\mathrm{p})$ process given by: $\pi_{t}=\alpha+\sum_{i=1}^{p} \beta_{i} \pi_{t-i}+u_{t}$, in which $\mathrm{AR}$ coefficients, $\beta_{i}$ (i=1 to $\mathrm{p}$ ) and $u_{t}$ is white noise error term. $\mathrm{SARC}=\sum_{1}^{p} \beta$. (see Dias and Marques (2005), Alper et al., (2016) for detail).

${ }^{6} \gamma=1-\frac{n}{T}$, in which $\mathrm{n}$ is the number of times the series crosses the mean over $\mathrm{T}$ time periods. Thus, The ratio, $\frac{n}{T}$ gives the degree of mean reversion.
} 
generalized least squares (GLS). The maximum $\operatorname{lag}(\mathrm{p})$ is chosen using Schwarz information criterion.

\section{Table 4.2: Measures of Persistence of Inflation}

\begin{tabular}{ccccccc}
\hline \multirow{2}{*}{ Time period } & \multicolumn{2}{c}{ Food inflation } & \multicolumn{2}{c}{ Non-food inflation } & \multicolumn{2}{c}{ General inflation } \\
\cline { 2 - 7 } & SARC:AR(p) & $\boldsymbol{\gamma}$ & SARC:AR(p) & $\boldsymbol{\gamma}$ & SARC:AR(p) & $\boldsymbol{\gamma}$ \\
\hline $1975-1991$ & -0.06 & 0.59 & 0.61 & 0.65 & 0.06 & 0.59 \\
\hline $1992-2018$ & -0.41 & 0.52 & 0.73 & 0.81 & -0.16 & 0.51 \\
\hline $1975-2018$ & -0.32 & 0.57 & 0.71 & 0.73 & -0.08 & 0.57 \\
\hline
\end{tabular}

Table 4.2 reports estimates of persistence measures for inflation in food and non-food sectors. The results of both estimates indicate that non-food inflation has become significantly more persistent than food inflation over the entire sample period, reflecting that it takes longer time for inflation in non-food sector to return to its mean level after a shock. Further, the persistence of non-food inflation has increased during the post-1991 period as compared to the pre-1991 period. While, food inflation exhibits a reduction in persistence over 1992-2018 period. Overall, the shocks to food prices are relatively transitory as compared to their non-food counterparts, making the general inflation to be weakly persistent during the study period.

\subsection{Econometric Results}

Prior to the main econometric analysis, we applied two pre-estimation tests. At first, unit root test is done to ascertain the stationarity of each variable included in this study. Secondly, a cointegration test was checked to determine the existence of long run relationship among variables.

\subsubsection{Unit Root Test results}

Performing unit root test is very important to determine the order of integration of the variables and to avoid the occurrence of spurious regressions. Augmented Dickey Fuller (ADF) unit root test is the most widely used stationary test although it has poor size and power properties and may not be reliable for small sample data set. As a result, to address limitations associated with standard ADF test, a modified Dickey-Fuller unit root test proposed by Elliott et al. (1996) in which the series has been transformed by a generalized least-squares regression called Dicky- 
Fuller generalized least square (DF-GLS) de-trending test was conducted to find out the existence of unit root in each of the time series.

Further, structural breaks may occur due to wars, natural disasters and policy changes and may affect the stationarity of time series and thus lead the unit-root tests without considering structural breaks to erroneously reject the stationarity of data. Accordingly, we also employed Zivot-Andrews (1992) unit-root test which accounts for possible endogenous structural breaks to ensure the robustness of our stationarity results. The null hypothesis in both DF-GLS and ZivotAndrews tests is that data series are non-stationary (contain unit root) against the alternative hypothesis of a Stationary process.

As can be observed in table 4.3, both unit-root tests indicate the variables are integrated of different orders. Food inflation, general inflation, labor force and investment are found stationary at levels, while the remaining variables become stationary after first differences. Note that the series is statistically significant and the null hypothesis of non-stationary can be rejected when test statistics values are greater than the critical values.

Table 4.3: Unit-root test results

\begin{tabular}{|c|c|c|c|c|c|c|}
\hline & & \multicolumn{2}{|c|}{ DF-GLS unit-root test } & \multicolumn{2}{|c|}{ Zivot-Andrews unit-root test } & \multirow{2}{*}{$\begin{array}{l}\text { Order of } \\
\text { Integration }\end{array}$} \\
\hline \multicolumn{2}{|c|}{ Variables } & intercept & $\begin{array}{l}\text { Intercept }+ \\
\text { trend }\end{array}$ & Break in trend & $\begin{array}{c}\text { Break in (intercept } \\
+ \text { trend) }\end{array}$ & \\
\hline \multirow[t]{2}{*}{$\ln$ RGDP } & $\mathrm{I}(0)$ & 3.294 & -0.194 & -0.578 & -0.607 & \multirow{2}{*}{$\mathrm{I}(1)$} \\
\hline & $\mathrm{I}(1)$ & $-5.202 *$ & $-6.575 *$ & $-7.599 *$ & $-7.658 *$ & \\
\hline \multirow[t]{2}{*}{ Food } & $\mathrm{I}(0)$ & $-6.439 *$ & $-6.665^{*}$ & $-7.174^{*}$ & $-7.622 *$ & \multirow{2}{*}{$\mathrm{I}(0)$} \\
\hline & $\mathrm{I}(1)$ & - & - & - & - & \\
\hline \multirow[t]{2}{*}{ Non-food } & $\mathrm{I}(0)$ & $-1.993 * *$ & -2.083 & -2.373 & -3.112 & \multirow{2}{*}{$\mathrm{I}(1)$} \\
\hline & $\mathrm{I}(1)$ & $-12.532 *$ & $-12.404^{*}$ & $-12.402 *$ & $-13.322^{*}$ & \\
\hline \multirow[t]{2}{*}{ Inflation } & $\mathrm{I}(0)$ & $-6.007 *$ & $-6.145 *$ & $-6.601 *$ & $-7.205^{*}$ & \multirow{2}{*}{$\mathrm{I}(0)$} \\
\hline & $\mathrm{I}(1)$ & - & - & - & - & \\
\hline \multirow[t]{2}{*}{ ln labor force } & $\mathrm{I}(0)$ & -1.408 & $-2.935 * * *$ & $-6.410 *$ & $-7.047 *$ & \multirow{2}{*}{$\mathrm{I}(0)$} \\
\hline & $\mathrm{I}(1)$ & - & - & - & - & \\
\hline \multirow[t]{2}{*}{ ln investment } & $\mathrm{I}(0)$ & -0.806 & $-3.898 *$ & $-4.885 * *$ & $-5.873 *$ & \multirow{2}{*}{$\mathrm{I}(0)$} \\
\hline & $\mathrm{I}(1)$ & - & - & - & - & \\
\hline \multirow{2}{*}{$\begin{array}{c}\ln \\
\text { expenditure }\end{array}$} & $\mathrm{I}(0)$ & $-2.047 * *$ & -2.261 & -3.155 & -3.966 & \multirow{2}{*}{$\mathrm{I}(1)$} \\
\hline & $\mathrm{I}(1)$ & $-5.125 *$ & $-5.227 *$ & $-5.202 *$ & $-5.533 * *$ & \\
\hline \multirow[t]{2}{*}{$\ln$ M2-GDP } & $\mathrm{I}(0)$ & -0.546 & -1.27 & -2.676 & -2.697 & \multirow{2}{*}{$\mathrm{I}(1)$} \\
\hline & $\mathrm{I}(1)$ & $-4.544 *$ & $-5.954 *$ & $-6.922 *$ & $-7.717 *$ & \\
\hline \multirow[t]{2}{*}{ ln openness } & $\mathrm{I}(0)$ & -1.02 & -1.548 & -2.233 & -3.783 & \multirow{2}{*}{$\mathrm{I}(1)$} \\
\hline & $\mathrm{I}(1)$ & $-5.859 *$ & $-6.011 *$ & $-4.779 * *$ & $-9.401 *$ & \\
\hline
\end{tabular}

Note: $* * *$ an $* * *$ denote statistical significant at $1 \%, 5 \%$ and $10 \%$ significant levels respectively. $\mathrm{I}(0)$ and $\mathrm{I}(1)$ represent at levels and first differences respectively. The critical values of DF-GLS test at 1\%,5\% and 10\% levels 
are: $-2.621,-1.949,-1.612$ for intercept and $-3.770,-3.190$ and -2.890 for both intercept and trend respectively. Further, The critical values of Zivot-Andrews test at $1 \%, 5 \%$ and $10 \%$ levels are: $-4.93,-4.42$, and -4.11 for break in trend; and $-5.57,-5.08$ and -4.82 for break in both intercept and trend respectively.

\subsubsection{Cointegration test}

Following that our variables found to have different integrated orders (mix of I(0) and I(1) processes), we employed Pesaran et al. (2001) ARDL bounds test for cointegration to test the existence of a long-run cointegrating relationship among our variables. ARDL bounds testing approach assumes a null hypothesis of no cointegration and it can be rejected if the F-statistic exceeds the critical value for upper bound, I(1). The null hypothesis cannot be rejected if the F statistic is lower than the critical value for lower bound, I(0). The finite-sample and asymptotic critical values and approximate $\mathrm{p}$-values for the $\mathrm{F}$ and $\mathrm{t}$-statistics are obtained via the response surface regressions results of Kripfganz and Schneider (2018).

Table 4.4 shows, in all cases, that the Pesaran et al. (2001) bounds test is inconclusive and cannot surely indicate the existence of cointegration as the F-statistic falls between the critical values of the lower and upper bounds at 5\% significant level.

Table 4.4: Pesaran et al. (2001) Bounds test for cointegration ${ }^{7}$

\begin{tabular}{cccc}
\hline & $\begin{array}{c}\text { Model with } \\
\text { Food }\end{array}$ & $\begin{array}{c}\text { Model with } \\
\text { Non-food }\end{array}$ & $\begin{array}{c}\text { Model with } \\
\text { General Inflation }\end{array}$ \\
\hline F-statistic & 3.245 & 3.233 & 3.310 \\
\hline Kripfganz and Schneider & Lower bound, I(0): 3.930 @ $1 \% ; 2.834$ @ 5\% and 2.371 @ 10\% level \\
(2018) Critical values & Upper bound, I(1): 5.659 @ $1 \% ; 4.222 @ 5 \%$ and 3.610 @ 10\% level \\
\hline Wald test & 14.40 & 17.80 & 15.03 \\
(p-value) & $(0.000)$ & $(0.000)$ & $(0.000)$ \\
\hline
\end{tabular}

As a result, we further perform Wald tests of composite linear hypotheses to confirm whether the long run coefficients are jointly statistically significantly different from zero, and hence to get a statistical evidence for the existence of a long-run relationship. The Wald tests results indicate the existence of long run cointegrating relationship in all cases at $1 \%$ level of significance.

\footnotetext{
${ }^{7}$ Since the validity of ARDL bounds test relies on the assumptions of homoscedasticity and no autocorrelation as well as stability of the coefficients over time, we checked all diagnostics and found homoscedastic and serially uncorrelated error terms. Further, the CUSUM squared stability test shows the stability of parameters over the study period.
} 


\subsubsection{Threshold Auto-regressive (TAR) model results}

As discussed in section 4.1 and 4.2, the trends, degree of price variations (volatility) and the time taken for converging to equilibrium after shock (persistency) are quite dissimilar for inflation in food and non-food sectors. Further, as noted in Walsh and Yu (2012), food inflation has different distributional impact from inflation in non-food items in the economy. Non-food inflation has more worsening impact on income inequality in both rural and urban areas than food counterparts. On the other hand, food inflation will have more adverse effect on urban households compared to rural ones. Hence, undertaking a sector-specific threshold analysis taking food and non-food inflation separately is quite worthwhile for optimal inflation targeting.

Prior to the investigation of threshold effects in inflation-growth nexus, we first test for the existence of significant threshold effects of inflation on economic growth over the study period. In this regard, the Bai and Perron (1998) testing method is used as a threshold specification (threshold value estimation) method. As reported in table 4.5, the null hypothesis of no threshold (linear model) is rejected at 1\% significant level against one threshold in cases of food inflation and general inflation and at 5\% level for non-food. Further, in the second hypothesis, the null of one threshold (two-regime model) cannot be rejected in favor of two-thresholds. In short, the Bai-Perron (1998) threshold test results of table 4.5 indicate the existence of a single inflationary threshold value (two-regime model) in our analysis. The results appear to suggest relationship between inflation and growth is found to be non-linear.

Table 4.5: Inflation threshold test results

\begin{tabular}{|c|c|c|c|c|c|c|c|c|}
\hline \multirow{3}{*}{ Threshold test } & \multicolumn{6}{|c|}{ Scaled F-statistic } & \multicolumn{2}{|c|}{$\begin{array}{c}\text { Bai-Perron (2003) } \\
\text { Critical value }\end{array}$} \\
\hline & \multicolumn{2}{|c|}{ Food inflation } & \multicolumn{2}{|c|}{ Non-food inflation } & \multicolumn{2}{|c|}{ General inflation } & \multirow{2}{*}{$1 \%$} & \multirow{2}{*}{$5 \%$} \\
\hline & 1 & 2 & 1 & 2 & 1 & 2 & & \\
\hline $\begin{array}{l}\text { Ho: no threshold } \\
\text { H1: one threshold }\end{array}$ & $17.03 *$ & $15.7 *$ & $12.78 * *$ & $12.49 * *$ & $15.44 *$ & $13.85^{* *}$ & 15.37 & 11.47 \\
\hline $\begin{array}{l}\text { Ho: one threshold } \\
\text { H1: two threshold }\end{array}$ & 10.63 & 9.47 & 4.1 & 6.75 & 6.51 & 6.2 & 16.84 & 12.95 \\
\hline
\end{tabular}

Note: *, and ** denote statistical significant at $1 \%$, and $5 \%$ significant levels respectively.

Following the existence of significant inflationary threshold effects, we apply the TAR model to examine the effects of inflation on growth below and above the threshold values. As presented in table 4.6, the threshold values for food, non-food and general inflation are found to be $10 \%, 8 \%$ and 9\% respectively. Comparable threshold levels were suggested in Yabu and Kessy (2015); 
Rao and Abate (2015); Abis and Cherkos (2018). Note that a dummy variable ${ }^{8}$ is included in our model so as to account for the impact of policy change (economic reform) made following the political transition from Derg to EPRDF in 1992, but it is found insignificant and brings no effect on our results.

The TAR model results considering the three cases of inflation as threshold variables consistently indicate that inflation is found to have significant growth-enhancing effects on economic growth below each threshold level (at low-inflation regime). Beyond the threshold values, however, the inflationary effects turn to be negative. i.e. there does exist a significant negative relationship between inflation and growth at high inflation regime. After all, the results suggest that low inflation tends to have growth-stimulating impact, while high inflation will have a negative influence on growth.

Table 4.6: TAR model results

\begin{tabular}{|c|c|c|c|c|c|c|}
\hline \multirow{2}{*}{$\begin{array}{l}\text { Threshold } \\
\text { variable }\end{array}$} & \multicolumn{2}{|c|}{ Food } & \multicolumn{2}{|c|}{ Non-food } & \multicolumn{2}{|c|}{ Inflation } \\
\hline & 1 & 2 & 1 & 2 & 1 & 2 \\
\hline Threshold $(T)$ & 10.06 & 10.06 & 8.13 & 8.2 & 8.8 & 8.8 \\
\hline Food $<T$ & $\begin{array}{l}0.007 * \\
(0.002)\end{array}$ & $\begin{array}{l}0.007 * * \\
(0.002)\end{array}$ & - & - & - & - \\
\hline Food $>=T$ & $\begin{array}{c}-0.003 * * \\
(0.001) \\
\end{array}$ & $\begin{array}{c}-0.003 * * \\
(0.001) \\
\end{array}$ & - & - & - & - \\
\hline Non-food $<T$ & - & - & $\begin{array}{l}0.012 * \\
(0.004)\end{array}$ & $\begin{array}{l}0.012^{*} \\
(0.004)\end{array}$ & - & - \\
\hline Non-food $>=T$ & - & - & $\begin{array}{r}-0.01 * * \\
(0.005)\end{array}$ & $\begin{array}{c}-0.01 * * * \\
(0.006)\end{array}$ & - & - \\
\hline Inflation $<T$ & - & - & - & - & $\begin{array}{c}0.009 * * \\
(0.004)\end{array}$ & $\begin{array}{c}0.009 * * \\
(0.004)\end{array}$ \\
\hline Inflation $>=T$ & - & - & - & - & $\begin{array}{c}-0.004 * * * \\
(0.002)\end{array}$ & $\begin{array}{c}-0.004 * * \\
(0.002)\end{array}$ \\
\hline \multicolumn{7}{|c|}{ Non-threshold variables } \\
\hline $\ln$ labor force & $2.28 *(0.16)$ & $2.25^{*}(0.19)$ & $2.5^{*}(0.23)$ & $2.55 *(0.24)$ & $2.29 *(0.16)$ & $2.25 *(0.19)$ \\
\hline ln investment & $0.77 *(0.22)$ & $0.80 *(0.25)$ & $0.52 * *(0.19)$ & $0.49 * *(0.23)$ & $0.76^{*}(0.22)$ & $0.8 *(0.25)$ \\
\hline ln expenditure & $0.24 * *(0.11)$ & $0.28 * * *(0.15)$ & $0.23 * *(0.11)$ & $0.17(0.17)$ & $0.26^{* *}(0.11)$ & $0.31 * *(0.16)$ \\
\hline $\ln \mathrm{M} 2 / \mathrm{GDP}$ & $-0.78 *(0.13)$ & $-0.83 *(0.17)$ & $-1.06 *(0.12)$ & $-1.01 *(0.17)$ & $-0.79 *(0.13)$ & $-0.85^{*}(0.17)$ \\
\hline ln Openness & $-0.74 *(0.12)$ & $-0.77 *(0.15)$ & $-0.7 *(0.14)$ & $-0.66 *(0.18)$ & $-0.75^{*}(0.13)$ & $-0.79 *(0.16)$ \\
\hline Dummy & - & $0.05(0.144)$ & - & $-0.07(0.128)$ & - & $0.07(0.153)$ \\
\hline $\mathrm{R}^{2}\left[\operatorname{adj}-\mathrm{R}^{2}\right]$ & 0.977 [0.971] & $0.977[0.97]$ & $0.979[0.974]$ & $0.979[0.973]$ & $0.976[0.97]$ & 0.976 [0.969] \\
\hline $\begin{array}{c}\text { F-stat } \\
{[p \text {-value }]}\end{array}$ & $\begin{array}{l}163.16 \\
{[0.000]}\end{array}$ & $\begin{array}{c}140.98 \\
{[0.000]}\end{array}$ & $\begin{array}{c}191.17 \\
{[0.000]}\end{array}$ & $\begin{array}{c}166.12 \\
{[0.000]}\end{array}$ & $\begin{array}{l}155.97 \\
{[0.000]}\end{array}$ & $\begin{array}{c}135.14 \\
{[0.000]}\end{array}$ \\
\hline
\end{tabular}

${ }^{8}$ Dummy $=\left\{\begin{array}{l}0 \text { if } 1975-1991 \\ 1 \text { if } 1992-2018\end{array}\right.$ 


\begin{tabular}{ccccccc}
\hline $\begin{array}{c}\text { Breusch-Godfrey } \\
\text { Serial Correlation } \\
\text { LM Test [p-value] }\end{array}$ & $\begin{array}{c}1.353 \\
{[0.274]}\end{array}$ & $\begin{array}{c}1.111 \\
{[0.343]}\end{array}$ & $\begin{array}{c}1.211 \\
{[0.312]}\end{array}$ & $\begin{array}{c}1.176 \\
{[0.322]}\end{array}$ & $\begin{array}{c}2.251 \\
{[0.123]}\end{array}$ & $\begin{array}{c}1.81 \\
{[0.183]}\end{array}$ \\
\hline $\begin{array}{c}\text { Heteroscedasticity } \\
\text { Test: ARCH } \\
\text { [p-value] }\end{array}$ & $\begin{array}{c}0.252 \\
{[0.619]}\end{array}$ & $\begin{array}{c}0.098 \\
{[0.756]}\end{array}$ & $\begin{array}{c}1.421 \\
{[0.240]}\end{array}$ & $\begin{array}{c}1.775 \\
{[0.191]}\end{array}$ & $\begin{array}{c}1.136 \\
{[0.293]}\end{array}$ & $\begin{array}{c}0.568 \\
{[0.456]}\end{array}$ \\
\hline $\begin{array}{c}\text { Jarque-Bera } \\
\text { Normality Test } \\
\text { [p-value] }\end{array}$ & $\begin{array}{c}0.404 \\
{[0.817]}\end{array}$ & $\begin{array}{c}0.486 \\
{[0.784]}\end{array}$ & $\begin{array}{c}0.095 \\
{[0.954]}\end{array}$ & $\begin{array}{c}0.185 \\
{[0.912]}\end{array}$ & $\begin{array}{c}0.343 \\
{[0.842]}\end{array}$ & $\begin{array}{c}0.498 \\
{[0.779]}\end{array}$ \\
\hline $\begin{array}{c}\text { CUSUM stability } \\
\text { test (at 5\% level) }\end{array}$ & Stable & stable & stable & stable & stable & Stable \\
\hline
\end{tabular}

Note: The figures shown in brackets are standard errors. *,** and *** denote statistical significant at $1 \%, 5 \%$ and $10 \%$ significant levels respectively. Model- 1 represents model without dummy and model-2 with dummy.

Considering the effect of other growth regressors (non-threshold variables) included in the model, the model results invariably show that labor force, investment and government expenditure are found to have significant positive effect on growth, as expected. In contrast, trade openness and broad money supply are negatively associated with economic growth over the study period.

\subsubsection{Further Discussion: Robustness Checks}

The robustness of our results is proved in different ways considering the general inflation as a threshold variable in this section.

Table 4.7: Robustness checks

\begin{tabular}{|c|c|c|c|c|}
\hline $\begin{array}{l}\text { Threshold variable: } \\
\text { Inflation }\end{array}$ & $\begin{array}{l}\text { Time period } \\
(1975-2015)\end{array}$ & $\begin{array}{l}\text { Dep. Variable }{ }^{\mathbf{1 0}} \\
(\ln \text { RGDP-PC) }\end{array}$ & \multicolumn{2}{|c|}{$\begin{array}{l}\text { Robustness to adding } \\
\text { Interaction terms }\end{array}$} \\
\hline Threshold $(T)$ & $10.7 \%$ & $10.4 \%$ & $8.8 \%$ & $8.8 \%$ \\
\hline Inflation $<T$ & 0.001 & 0.003 & $0.01 * *$ & $0.01 * *$ \\
\hline Inflation $>=T$ & $-0.002 * *$ & $-0.003 *$ & $-0.005 * *$ & $-0.005 * *$ \\
\hline \multicolumn{5}{|l|}{ Below threshold } \\
\hline Inflation* In expenditure & - & - & -0.002 & - \\
\hline Inflation $* \ln M 2 / G D P$ & - & - & - & -0.002 \\
\hline \multicolumn{5}{|l|}{ Above threshold } \\
\hline Inflation $*$ In expenditure & - & - & $-0.002 * *$ & - \\
\hline Inflation*ln $M 2 / G D P$ & - & - & - & $-0.001 * *$ \\
\hline Non-threshold variables & & & & \\
\hline
\end{tabular}

\footnotetext{
${ }^{9}$ Robustness test to excluding outliers in dependent variable (ln RGDP) so as to control for the influence of extreme values on our regression results.

${ }^{10}$ We also checked the threshold for food and non-food inflation in regression using $\ln$ GDP-PC as dependent variable, and the results indicate that the threshold for food inflation is $10.7 \%$ and for non-food inflation is $7.8 \%$. In both cases, inflation is found to have a significant negative relationship with economic growth beyond the threshold.
} 


\begin{tabular}{|c|c|c|c|c|}
\hline ln labor force & $1.86^{*}$ & $0.86^{*}$ & $2.39 *$ & $2.39 *$ \\
\hline ln investment & $0.37 *$ & $0.63 *$ & $0.664 *$ & $0.672 *$ \\
\hline ln expenditure & 0.02 & $0.14 *$ & $0.257 * *$ & $0.254 * *$ \\
\hline ln M2/GDP & $-0.73 *$ & $-0.98^{*}$ & $-0.851 *$ & $-0.844 *$ \\
\hline ln Openness & $-0.26^{*}$ & $-0.4^{*}$ & $-0.767 *$ & $-0.768 *$ \\
\hline $\begin{array}{c}\mathrm{R}^{2} \\
{\left[\operatorname{adj}-\mathrm{R}^{2}\right]}\end{array}$ & $\begin{array}{c}0.993 \\
{[0.991]}\end{array}$ & $\begin{array}{c}0.967 \\
{[0.959]}\end{array}$ & $\begin{array}{c}0.979 \\
{[0.971]}\end{array}$ & $\begin{array}{c}0.979 \\
{[0.971]}\end{array}$ \\
\hline $\begin{array}{c}\text { F-stat } \\
{[\mathrm{p}-\mathrm{value}]}\end{array}$ & $\begin{array}{c}472.4 \\
{[0.000]}\end{array}$ & $\begin{array}{l}114.2 \\
{[0.000]}\end{array}$ & $\begin{array}{c}132.94 \\
{[0.000]}\end{array}$ & $\begin{array}{c}132.1 \\
{[0.000]}\end{array}$ \\
\hline $\begin{array}{c}\text { Threshold test: scaled F-stat } \\
\text { (Ho: no threshold) }\end{array}$ & $20.33 *$ & $22.76^{*}$ & $15.64 *$ & $15.35^{*}$ \\
\hline \multicolumn{5}{|l|}{ Model Diagnostics } \\
\hline $\begin{array}{c}\text { Breusch-Godfrey Serial Correlation } \\
\text { LM Test [p-value] }\end{array}$ & $\begin{array}{c}0.158 \\
{[0.855]}\end{array}$ & $\begin{array}{c}0.025 \\
{[0.976]}\end{array}$ & $\begin{array}{c}1.148 \\
{[0.332]}\end{array}$ & $\begin{array}{l}1.062 \\
{[0.36]}\end{array}$ \\
\hline $\begin{array}{l}\text { Heteroscedasticity Test: ARCH [p- } \\
\text { value] }\end{array}$ & $\begin{array}{c}0.157 \\
{[0.694]}\end{array}$ & $\begin{array}{c}0.01 \\
{[0.921]}\end{array}$ & $\begin{array}{l}0.403 \\
{[0.53]}\end{array}$ & $\begin{array}{c}0.395 \\
{[0.534]}\end{array}$ \\
\hline $\begin{array}{l}\text { Jarque-Bera Normality Test } \\
\text { [p-value] }\end{array}$ & $\begin{array}{c}2.778 \\
{[0.249]}\end{array}$ & $\begin{array}{c}1.322 \\
{[0.516]}\end{array}$ & $\begin{array}{c}0.534 \\
{[0.766]}\end{array}$ & $\begin{array}{c}0.469 \\
{[0.791]}\end{array}$ \\
\hline CUSUM Stability tests & Stable & stable & stable & stable \\
\hline
\end{tabular}

Note: $*$,and $* *$ denote statistical significant at $1 \%$, and $5 \%$ significant levels respectively.

First, we exclude the upper extreme values (outliers) in the dependent variable (ln RGDP) observed in the last three years of the study period and perform the regression analysis again. The model results (in second column of table 4.7) confirm inflationary threshold value of $10.7 \%$ and the results obtained from using $\ln$ RGDP-PC as alternative indicator for economic growth (dependent variable) indicate inflation threshold level of 10.4\%. Further, both robustness tests to excluding extreme values and alternative proxy for growth invariably reveal that inflation is still found to have a significant worsening effect on growth after its threshold level (during high inflationary periods). Concerning the robustness tests to adding interaction terms as reported in last two columns of table 4.7), the TAR estimation results show that increase in government expenditure and broad money supply have significant negative effect in the inflation-growth relationship after the threshold level, perhaps suggesting that expansionary fiscal and monetary policies aggravate the adverse impact of inflation on growth during high inflationary periods. In contrast, these policies do not exert inflationary pressures on growth during low inflationary periods.

\section{Conclusion}

The nature of inflation-growth relationship and optimal level of inflation target have remained controversial concerns in both theoretical and empirical literatures. Accordingly, this study aims 
at investigating whether non-linearities (threshold effects) in inflation-growth nexus exist in Ethiopia over the last four decades (1975-2018). This study departs from previous works since it considers inflation in food and non-food sectors separately. The degree of volatility and persistence of food and non-food inflation are also assessed in the study.

When inflation is disaggregated into food and non-food inflation, the results reveal inflation in food items has been a key contributor to general (headline) inflation in Ethiopia and food inflation follows a more consistent trend with general inflation. Further, our measures of volatility and persistence show that food inflation has become more volatile and less-persistent as compared to its non-food counterpart, reflecting that food price shocks are relatively transitory and take a shorter time to revert to equilibrium after a shock. On the other hand, the main TAR model results and robustness tests indicate the existence of inflation threshold level in a range of 9-10\%. In particular, the thresholds for inflation in food and non-food sectors are $10 \%$ and $8 \%$ respectively. In all cases of inflation, our results confirm a growth-reducing effect of inflation after the threshold level, which are robust to excluding outliers, alternative measure of growth and adding interaction terms. Further, expansionary fiscal and monetary policies are found to worsen the adverse effect of inflation on growth during high inflationary periods.

After all, we suggest some policy implications in light of our empirical results and conclusions. First, given different trends, degree of volatilities and persistence, policy makers need to consider the specific behaviors of food and non-food prices so as to detect underlying inflationary shocks and pressures in the economy. Second, the identified threshold levels of inflation in the study imply the need for implementing appropriate fiscal and monetary policies to bring inflation down to a single-digit level to avoid the growth detrimental effects of high inflation. Further, determining sector-specific inflation threshold for growth might provide useful information about the appropriate inflation target setting. Finally, the main sources of inflationary pressures and the precise transmission channels through which inflation exerts an adverse effect on economic growth are not yet addressed in this study and hence deserve important concern in future studies. 


\section{Acknowledgements}

None.

\section{Funding}

No funding was received.

\section{Competing interests}

The author declares no competing interest.

Availability of data and materials

The data used in this study will be available upon request.

\section{References}

Abis G. amd Cherkos, M. (2018). Do Prices Influence Economic Growth? Estimating the Inflation Threshold of the Ethiopian Economy. Journal of Economics and Sustainable Development, 9(1).

Admasu, F. (2014). Inflation And Economic Growth: An Estimating of Threshold Level of Inflation in Ethiopia. Master's Thesis, Addis Ababa University, Ethiopia.

Adusei, M. (2012). The Inflation-Growth Nexus: Estimating the Threshold Effect for South Africa. Journal of Money, Investment and Banking, 26.

Alper, C.E., Hobdari, N. and Uppal, A. (2016). Food Inflation in Sub-Saharan Africa: Causes and Policy Implications. IMF Working Paper No. 16/247.

Ashagrie, D. (2015). Inflation - Growth Nexus in Ethiopia: Evidence from Threshold Auto Regressive Model. Ethiopian Journal of Economics, XXIV(1).

Aydin, C., Esen, O. and Bayrak, M. (2016). Inflation and Economic Growth: A Dynamic Panel Threshold Analysis for Turkish Republics in Transition Process. Procedia - Social and Behavioral Sciences, 229: 196 - 205. https://doi: 10.1016/j.sbspro.2016.07.129.

Aydin, S. and Esen, O. (2017). Inflationary Threshold Effects on the Relationship between Unemployment and Economic Growth: Evidence from Turkey. International Journal of Economic Perspectives, 11(2): 88-97.

Ayyoub, M. (2016). Inflation-Growth Nexus in Developing Economies: New Empirical Evidence from a Dis-aggregated Approach. Working Paper, No. 1602, Johannes Kepler University of Linz, Department of Economics, Linz. http://hdl.handle.net/10419/155474.

Behera, J. and Mishra, A.K. (2017). The Recent Inflation Crisis and Long-run Economic Growth in India: An Empirical Survey of Threshold Level of Inflation. South Asian Journal of Macroeconomics and Public Finance, 6(1):105-132. http://doi:10.1177/2277978717695154.

Chu, J. F., Sek, K.S. and Ismail, M.T. (2019). Threshold Effects of Inflation on Economic Growth: Evidence from Dynamic Panel Threshold Regression Analysis for 18 Developed Economies. Journal of Management, Economics, and Industrial Organization, 3(1):51-62. http://doi.org/10.31039/jomeino.2019.3.1.4.

Dias, D. and Marques, C.R. (2005). Using Mean Reversion As A Measure of Persistence. Euro-system Inflation Persistence Network, Working Paper No.450/2005.

Fekadu, D.G. (2012). Relationship between Inflation and Economic Growth in Ethiopia: An Empirical Analysis, 1980-2011. Master's Thesis, University of Oslo.

Gokal, V. and Hanif, S. (2004). Relationship Between Inflation and Economic Growth. Working Paper No. 2004/04, Reserve Bank of Fiji.

Haans, R. and He, Z.L. (2016). Thinking about U: Theorizing and Testing U- and inverted U shaped Relationships in Strategy Research. Strategic Management Journal. https://DOI:10.1002/smj.2399.

Khan, M.S. and Senhdji, A.S. (2001). Threshold Effects in the Relationship Between Inflation and Growth. IMF Staff Papers, 48(1). 
Kremer, S., Bick, A. and Nautz, D. (2011). Inflation and Growth: New Evidence From a Dynamic Panel Threshold Analysis.

Masiyandima, N., Ngundu, T., Kupeta, K., P. S. Moyo, P.S. and Ngwenya, S. (2018). Optimal Inflation For Zimbabwe. RBZ Working Paper No.1/2018.

Ndoricimpa, A. (2017). Threshold Effects of Inflation on Economic Growth in Africa: Evidence from a Dynamic Panel Threshold Regression Approach. Working Paper No. 249, African Development Bank Group.

Nkume, J-B. and Ngalawa, H. (2014). Optimal Inflation Threshold for Economic Growth in Malawi. Journal of Economics and Behavioral Studies, 6(12): 933-946.

Rao, P.N. and Abate, Y. (2015). Inflation and Economic Growth: Inflation Threshold Level Analysis for Ethiopia. International Journal of Ethics in Engineering \& Management Education, 2(5).

Rutayisire, M.J. (2015). Threshold Effects in the Relationship between Inflation and Economic Growth: Evidence from Rwanda. AERC Research Paper 293.

Sumon, K.K. and Miyan, Md. S. (2017). Inflation and Economic Growth: An Empirical Evidence of Bangladesh (1986-2016). International Journal of Economics and Financial Issues, 5(7):454-464.

Thanh, S.D. (2015). Threshold effects of inflation on growth in the ASEAN-5 countries: A Panel Smooth Transition Regression approach. Journal of Economics, Finance and Administrative Science, 20: 41-48. http://dx.doi.org/10.1016/j.jefas.2015.01.003.

Tung, L.T. and Thanh, P.T. (2015). Threshold in the Relationship between Inflation and Economic Growth: Empirical Evidence in Vietnam. Asian Social Science, 11(10). http://dx.doi.org/10.5539/ass.v11n10p105.

Walsh, J.P. and YU, J. (2012). Inflation and Income Inequality: Is Food Inflation Different? IMF Working Paper No. 12/147. http://dx.doi.org/10.5089/9781475504163.00.

Yabu, N. and Kessy, N.J. (2015). Appropriate Threshold Level of Inflation for Economic Growth: Evidence from the Three Founding EAC Countries. Applied Economics and Finance, 2(3). http://dx.doi.org/10.11114/aef.v2i3.966.

Yilmazkuday, H. (2011). Inflation Thresholds and Growth. International Economic Journal. https:// DOI: $\underline{10.1080 / 10168737.2012 .658831 .}$ 


\section{Appendix 1}

Table A1: Review of some recent studies on inflation-growth nexus

\begin{tabular}{|c|c|c|c|c|}
\hline Studies & $\begin{array}{l}\text { Study area } \\
\text { \& period }\end{array}$ & $\begin{array}{l}\text { Methodology } \\
\text { employed }\end{array}$ & Main findings & $\begin{array}{l}\text { Level of Threshold } \\
\text { inflation }\end{array}$ \\
\hline $\begin{array}{c}\text { Behera and } \\
\text { Mishira (2017) }\end{array}$ & $\begin{array}{c}\text { India } \\
(1990-2017)\end{array}$ & $\begin{array}{l}\text { ARDL model } \\
\text { Spline regression }\end{array}$ & $\begin{array}{l}\text { Inflation affects growth } \\
\text { negatively above the threshold }\end{array}$ & $4 \%$ \\
\hline $\begin{array}{l}\text { Adusei } \\
(2012)\end{array}$ & $\begin{array}{l}\text { South Africa } \\
(1965-2010)\end{array}$ & $\begin{array}{c}\text { Non-linear } \\
\text { regression model }\end{array}$ & $\begin{array}{c}\text { Inflation affects growth } \\
\text { negatively above the threshold }\end{array}$ & $7 \%$ \\
\hline $\begin{array}{l}\text { Majumder } \\
\text { (2016) }\end{array}$ & $\begin{array}{l}\text { Bangladesh } \\
(1975-2013)\end{array}$ & $\begin{array}{l}\text { error correction } \\
\text { model }\end{array}$ & $\begin{array}{l}\text { Long run positive relationship } \\
\text { between inflation and growth }\end{array}$ & \\
\hline $\begin{array}{c}\text { Sumon and } \\
\text { Miyan (2017) }\end{array}$ & $\begin{array}{l}\text { Bangladesh } \\
(1986-2016)\end{array}$ & $\begin{array}{l}\text { Conditional least } \\
\text { square method }\end{array}$ & $\begin{array}{l}\text { Inflation does not affect } \\
\text { growth beyond the threshed }\end{array}$ & $8 \%$ \\
\hline $\begin{array}{l}\text { Olu \& Idih } \\
\text { (2015) }\end{array}$ & $\begin{array}{c}\text { Nigeria } \\
(1980-2013)\end{array}$ & $\begin{array}{l}\text { OLS multiple } \\
\text { regression model }\end{array}$ & $\begin{array}{c}\text { Insignificant relationship } \\
\text { between inflation and growth }\end{array}$ & \\
\hline $\begin{array}{l}\text { Masiyandima } \\
\text { et al. (2018) }\end{array}$ & $\begin{array}{c}\text { Zimbabwe } \\
(1980-1997) \\
(2009-2017)\end{array}$ & $\begin{array}{l}\text { Quadratic threshold } \\
\text { model }\end{array}$ & $\begin{array}{l}\text { Positive relationship below the } \\
\text { threshold and negative above } \\
\text { the threshold }\end{array}$ & $\begin{array}{l}8.7 \% \text { for } 1980-1997 \\
4.6 \% \text { for } 2009-2017\end{array}$ \\
\hline $\begin{array}{l}\text { Nkume and } \\
\text { Ngalawa } \\
(2014)\end{array}$ & $\begin{array}{c}\text { Malawi } \\
(1980-2013)\end{array}$ & $\begin{array}{l}\text { Conditional Least } \\
\text { Squares Method }\end{array}$ & $\begin{array}{l}\text { greater marginal gains in real } \\
\text { GDP growth below than above } \\
\text { the optimal inflation threshold. }\end{array}$ & $17 \%$ \\
\hline $\begin{array}{c}\text { Tung and } \\
\text { Thanh (2015) }\end{array}$ & $\begin{array}{l}\text { Vietnam } \\
(1986-2013)\end{array}$ & $\begin{array}{l}\text { OLS, 2-SLS and } \\
\text { GMM method }\end{array}$ & $\begin{array}{l}\text { Inflation is harmful to growth } \\
\text { beyond the threshold level }\end{array}$ & $7 \%$ \\
\hline $\begin{array}{c}\text { Yabu and } \\
\text { Kessy (2015) }\end{array}$ & $\begin{array}{l}3 \text { East African } \\
\text { countries } \\
(1970-2013)\end{array}$ & $\begin{array}{l}\text { Random effects } \\
\text { panel data model }\end{array}$ & $\begin{array}{l}\text { Negative relationship between } \\
\text { inflation and growth beyond } \\
\text { the threshold level }\end{array}$ & $8.46 \%$ \\
\hline $\begin{array}{l}\text { Thanh } \\
\text { (2015) }\end{array}$ & $\begin{array}{l}\text { ASEAN-5 } \\
\text { countries } \\
(1980-2011)\end{array}$ & $\begin{array}{l}\text { Panel Smooth } \\
\text { Transition } \\
\text { Regression model }\end{array}$ & $\begin{array}{l}\text { negative relationship between } \\
\text { inflation and growth above the } \\
\text { threshold level }\end{array}$ & $7.84 \%$ \\
\hline $\begin{array}{l}\text { Aydin et al. } \\
\quad(2016)\end{array}$ & $\begin{array}{l}\text { five Turkish } \\
\text { Republics }\end{array}$ & $\begin{array}{c}\text { Dynamic Panel } \\
\text { Threshold Analysis }\end{array}$ & $\begin{array}{l}\text { Positive relationship below the } \\
\text { threshold and negative above } \\
\text { the threshold }\end{array}$ & $7.97 \%$ \\
\hline $\begin{array}{l}\text { Ayyoub } \\
(2016)\end{array}$ & $\begin{array}{c}113 \\
\text { developing } \\
\text { countries } \\
(1974-2013)\end{array}$ & $\begin{array}{l}\text { Dis-aggregated } \\
\text { analysis }\end{array}$ & $\begin{array}{l}\text { inflation impacts the growth of } \\
\text { industrial and services } \\
\text { sectors negatively, but positive } \\
\text { for agricultural sector }\end{array}$ & $\begin{array}{l}3.48 \% \text { - aggregate } \\
14.48 \% \text { - industry } \\
15.37 \% \text {-service } \\
40 \% \text { - agriculture }\end{array}$ \\
\hline $\begin{array}{l}\text { Ndoricimpa } \\
\text { (2017) }\end{array}$ & $\begin{array}{l}47 \text { African } \\
\text { countries } \\
(1970-2013)\end{array}$ & $\begin{array}{c}\text { Dynamic Panel } \\
\text { Threshold regression }\end{array}$ & $\begin{array}{c}\text { Inflation above the threshold } \\
\text { level affective growth } \\
\text { negatively }\end{array}$ & $\begin{array}{l}6.7 \% \text { - whole sample } \\
6.5 \% \text {-middle income } \\
9 \% \text { - low-income }\end{array}$ \\
\hline
\end{tabular}

